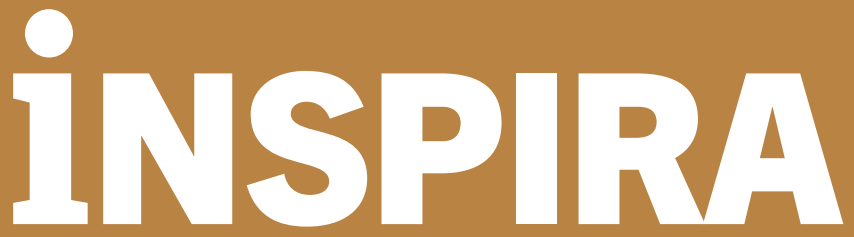

Tidsskrift for anestesi-, operasjon- og intensivsykepleiere

\title{
Målrettet ultralyd av vena cava inferior for vurdering av volumstatus utført av sykepleiere med en avansert funksjon - en systematisk litteraturstudie
}

\author{
Gro Helene Ek Visdal ${ }^{1,2}$ \\ RN, MNSc, Avansert Klinisk Sykepleier, Intensivsykepleier, Kardiologisk sykepleier \\ ${ }^{1}$ Medisinsk Overvåkning, Akershus Universitetssykehus, Norge \\ 2Lovisenberg Diakonale Høgskole, Norge \\ E-post: gro.helene.ek.visdal@gmail.com
}

\section{Vivi Lycke Christensen ${ }^{2,3}$}

RN, PhD

${ }^{2}$ Lovisenberg Diakonale Høgskole, Norge

${ }^{3}$ Universitetet i Sørøst-Norge, Norge

\section{Sammendrag}

Bakgrunn: Ultralydmåling av respirasjonsavhengige endringer i diameter av vena cava inferior kan hjelpe klinikeres vurderinger ved væskeresuscitering av hemodynamisk ustabile pasienter. Det er enkelt å gjennomføre, non-invasivt og krever lite opplæring. Studier har konkludert med at dersom sykepleiere med en avansert funksjon utfører målrettet ultralyd av vena cava inferior, kan det gi verdifull tilleggsinformasjon til kliniske vurderinger av volumstatus. Det er ikke funnet systematiske litteraturstudier som oppsummerer primærstudier der ultralyd av vena cava inferior for vurdering av volumstatus unders $\varnothing$ kes.

Hensikt: Unders $\varnothing$ ke om sykepleiere med en avansert funksjon kan utføre målrettet ultralyd av vena cava inferior for vurdering av volumstatus hos voksne pasienter.

Metode: Studiens design er en systematisk litteraturstudie, med systematiske $\varsigma \varnothing \mathrm{k}$ i databasene Cinahl, Medline, SweMed+, Cochrane Trials og Embase. Studiene ble kvalitetsvurdert ved hjelp av sjekkliste for Diagnostic Test Accuracy-studier fra Joanna Briggs Institute. Innhenting av korrekte ultralydbilder og pålitelig vurdering av volumstatus utført av sykepleiere med en avansert funksjon sammenliknet med legespesialister med ulik ekspertise på ultralyd ble analysert.

Resultater: Seks studier oppfylte inklusjonskriteriene. Totalt 35 sykepleiere i avanserte funksjoner innhentet til sammen 336 bilder av vena cava inferior. For innhenting av ultralydbilder var korrelasjon mellom sykepleierne og legespesialistene moderat til utmerket. For vurdering av volumstatus var korrelasjon adekvat til utmerket.

Konklusjon: Sammenstilling av funnene viste at sykepleiere med en avansert funksjon kan innhente korrekte ultralydbilder av vena cava inferior samt gjøre pålitelige vurderinger av volumstatus sammenliknet med legespesialister. Tilstrekkelig opplæring og trening er viktig.

Nøkkelord: sykepleier; systematisk litteraturstudie; ultralyd; vena cava inferior; volumstatus

(c) 2021 Gro Helene Ek Visdal \& Vivi Lycke Christensen. This is an Open Access article distributed under the terms of the Creative Commons Attribution 4.0 International License (http://creativecommons.org/licenses/by/4.0/). 


\section{Abstract}

Targeted ultrasound of the inferior vena cava for assessment of volume status performed by nurses with an advanced function - A systematic literature of the literature

Background: Ultrasound measurement of respiratory changes in the diameter of the inferior vena cava can assist clinicians' assessments in fluid resuscitation of hemodynamically unstable patients. It is easy to implement, non-invasive and requires little training. Studies have concluded that if nurses with an advanced function perform targeted ultrasound of the inferior vena cava, it can provide valuable additional information to clinical assessments of volume status. No systematic literature studies have been found that specifically review ultrasound of the inferior vena cava for assessment of volume status.

Aim: To review whether nurses with an advanced function can perform targeted ultrasound of the inferior vena cava to assess volume status in adult patients.

Method: The study design is a systematic literature review, with systematic searches in the databases Cinahl, Medline, SweMed +, Cochrane Trials and Embase. The studies were quality assessed using a checklist for Diagnostic Test Accuracy studies from the Joanna Briggs Institute. The obtaining of valid ultrasound images and reliable interpretation of ultrasound examinations performed by nurses with an advanced function were analyzed.

Results: Six studies met the inclusion criteria. A total of 35 nurses in advanced functions obtained a total of 336 images of the inferior vena cava. For obtaining ultrasound images, the correlation between the nurses and the medical specialists was moderate to excellent. For assessment of volume status, correlation was adequate to excellent.

Conclusion: Compilation of the findings showed that nurses with an advanced function can obtain adequate ultrasound images of the inferior vena cava and perform reliable assessments of volume status. Adequate education and training is important.

Keywords: inferior vena cava; nurse; systematic review; ultrasound; volume status

\section{Innledning}

I de senere år har det vært $\varnothing$ kende fokus på at kun 50 \% av hemodynamisk ustabile pasienter vil respondere på væsketilførsel med $\varnothing \mathrm{kt}$ cardiac output $(1,2)$. Samtidig har stor positiv væskebalanse blitt assosiert med $\varnothing \mathrm{kt}$ mortalitet (3-5). Diagnostiske verktøy som ultralyd har i økende grad blitt tatt i bruk hos pasienter med hypotensjon og sjokk (6). Ultralydmåling av respirasjonsavhengige endringer i diameter av vena cava inferior for vurdering av intravaskulært volum er et eksempel på en slik undersøkelse. Metoden anses å være mer presis enn måling av sentralt venetrykk (7). Ultralyd gir ikke definitive diagnoser, men det antas at undersøkelsen kan gi verdifull informasjon og potensielt være livreddende hos kritisk syke pasienter, gitt at det utføres av trenet personell (6).

En rekke studier har undersøkt om ultralyd av vena cava inferior egner seg til å vurdere hvorvidt pasienten vil respondere på væsketilførsel (1-3,8-11). Det nevnes særlig tilstander som sepsis og sjokk $(6,7,12,13)$, og hos pasienter som er kritisk syke (3,9-11). Til tross for at slike målinger anbefales for å predikere væskerespons, debatteres nytteverdi og nøyaktighet (8). Likevel er ultralydunders $\varnothing$ kelse av vena cava for vurdering av volumstatus i en særstilling (8). Det er enkelt å gjennomføre, non-invasivt, krever lite opplæring og studier har vist en bratt læringskurve hos utøverne $(1,8,14)$. Forskning viser 
videre at ultralydunders $\varnothing$ kelse av vena cava inferior er en kostnadseffektiv og tidseffektiv modalitet som på sikt er forventet å kunne bli standard behandling $(9,10)$. Imidlertid strides man om i hvilken grad metoden egner seg for pasienter med behov for kontrollert mekanisk ventilasjon kontra pasienter med spontan respirasjon $(1,3)$.

En systematisk oversikt fra 2018 indikerer at sykepleiere kan fremskaffe adekvate ultralydbilder og slik forbedre sikkerhet og suksessrate ved ulike prosedyrer som venekateter, nasogastrisk sonde og målinger av vena cava inferior (15). Funnene fra denne studien tyder også på at sykepleiere kan utføre ultralyd ved abdominale traumer med gode resultater (15). Sykepleieres bruk av ultralyd vil kunne bidra til at viktig informasjon blir tilgjengelig for behandlende lege, og slik medvirke til økt pasientsikkerhet (16). Ultralyd av vena cava inferior for vurdering av volumstatus utført av sykepleiere med en avansert funksjon kan tilføre en objektiv dimensjon i vurderingen av intravaskulært volum, og dermed forbedre diagnostisering og pasientbehandling (17-20). Med et stadig $\varnothing$ kende behov for helsetjenester, er det et begrunnet behov for å gjøre en ny vurdering av hvordan man bruker kompetansen til ulike faggrupper $(21,22)$. Oppgaveforskyvning, særlig mellom lege og sykepleier, har vist seg å være til fordel for pasientene (21). Klinisk unders $\varnothing$ kelsesmetodikk på avansert nivå, vurdering av pasientens helsebehov og kliniske beslutninger om diagnose, intervensjon og behandling er eksempler på dette $(23,24)$.

Studier har konkludert med at dersom sykepleiere med en avansert funksjon utfører målrettet ultralyd av vena cava inferior, kan det gi verdifull tilleggsinformasjon til kliniske vurderinger av volumstatus (17,20). Det er imidlertid ikke funnet systematiske litteraturstudier som kun undersøker ultralyd av vena cava inferior for vurdering av volumstatus. På bakgrunn av dette er det grunnlag for å gjøre en systematisk gjennomgang av eksisterende litteratur $(25,26)$. Hensikten med denne systematiske litteraturstudien er å undersøke om sykepleiere med en avansert funksjon kan utføre målrettet ultralyd av vena cava inferior for vurdering av volumstatus hos voksne pasienter.

Følgende forskningsspørsmål ble videre formulert:

1. Kan sykepleier med en avansert funksjon innhente korrekte ultralydbilder av vena cava inferior?

2. Kan sykepleier med en avansert funksjon gjøre pålitelige tolkninger av vena cava inferior med tanke på volumstatus?

Bruken av begrepet «sykepleiere med en avansert funksjon» er begrunnet i at det finnes en rekke ulike titler på spesialiserte og avanserte sykepleierfunksjoner og -roller, både i Norge og resten av verden. Bruken av disse titlene varierer fra land til land, og det er derfor vanskelig å begrense seg til bruken av norske titler som avansert klinisk sykepleier eller ulike spesialsykepleiertitler (22).

\section{Metode}

Denne artikkelen baserer seg på et mastergradsarbeid innen avansert klinisk sykepleie med spesialisering i intensivsykepleie. For å besvare forskningsspørsmålene ble studien 
utført som en systematisk litteraturstudie, og i henhold til retningslinjene fra Preferred Reporting Items for a Systematic Review and Meta-analysis of Diagnostic Test Accuracy Studies (PRISMA-DTA) (27,28). Det ble utarbeidet klare inklusjons- og eksklusjonskriterier for å sikre at alle relevante studier ble inkludert i den systematiske litteraturstudien. Artikler som oppfylte følgende kriterier ble inkludert: ultralyd av vena cava inferior for vurdering av volumstatus, voksne pasienter $>18$ år, kvantitative studier og fagfellevurderte primærstudier. Kun studier publisert på engelsk eller skandinaviske språk ble inkludert. Studier som ikke omhandlet ultralyd utført av sykepleier ble ekskludert.

\section{Søkestrategi}

For å sikre god kvalitet i søkeprosessen, ble opprinnelig søk planlagt og gjennomført sammen med spesialbibliotekar ved Medisinsk fag- og forskningsbibliotek ved Akershus universitetssykehus. Det ble gjort systematiske $s ø \mathrm{k}$ i databasene Cinahl, Medline, SweMed+ og Cochrane Trials. Søkene ble deretter kvalitetssikret av spesialbibliotekar ved Lovisenberg Diakonale Høgskole. På bakgrunn av få funn i SweMed+ og Cochrane Trials, ble det i tillegg s $\varnothing \mathrm{kt}$ i Embase. De samme s $\varnothing$ keordene ble benyttet for s $\varnothing \mathrm{k}$ i Google Scholar. Søkeordene ble tilpasset de ulike databasene, og gjennomført i perioden 19. november-13. desember 2019. S $\varnothing$ keordene som ble benyttet var nurs*, nurse, critical care nursing, nurse specialist og nurse practitioners kombinert med OR, ultrasonography, ultrasonograph*, ultrasound og v-scan kombinert med OR, og vena cava inferior, inferior vena cava kombinert med OR. Disse ble deretter kombinert med AND. I søkene ble elementene populasjon (P) og intervensjon (I) fra PICO-skjema (tabell 1) benyttet. Ytterligere avgrensning av søkene ble ikke gjort på bakgrunn av få funn (29). For å sikre identifisering av alle relevante studier, ble det ikke satt begrensninger på publikasjonsår. Referanselistene i tidligere publiserte systematiske oversikter og primærstudier som omhandlet ultralyd av vena cava ble gjennomgått for å avdekke relevante studier. Søk etter litteratur som ikke er indeksert i aktuelle referansedatabaser, såkalt grå litteratur (30), ble utført i databasen OpenGrey fra University of London. Et oppdatert søk ble utført av forfatterne i samarbeid med spesialbibliotekar februar 2021. Ingen ytterligere relevante studier ble identifisert.

Tabell 1: PICO-skjema

\begin{tabular}{llll}
\hline Populasjon & Intervensjon & Comparison & Outcome \\
\hline Nurses (expl) & Ultrasonography & Doctor & Inter-rater reliability \\
Nurs* & Ultrasonograph* & Physician & Correlation \\
Nurse Specialist+ & Ultrasound & Intensivist & Agreement \\
Nurse Practitioners+ & V-scan* & Cardiologist & Feasibility \\
Nursing+ & Scan* & Sonographer & Reliability \\
Critical care nursing & Vena cava inferior & Expert & Clinical competence \\
& Inferior vena cava & & Skill acquisition \\
& & & Fluid responsive* \\
& & & Volume responsive* \\
& & & Volume status \\
\hline
\end{tabular}




\section{Resultater av søk}

Basert på systematiske $\varsigma \varnothing \mathrm{k}$ i de ulike databasene ble det til sammen identifisert 101 artikler. Utvelgelse av artikler ble initialt utført av førsteforfatter og gjennomgått av sisteforfatter. I etterkant av oppdatert søk er prosessen med utvelgelse av artikler utført på nytt. Dette ble utført separat av førsteforfatter og sisteforfatter og deretter gjennomgått i fellesskap med endelig utvelgelse av artikler. Prosessen med opprinnelig søk og kritisk gjennomgang av artikler er dokumentert i PRISMA-flowchart (figur 1) (31). Søk i Google Scholar identifiserte 18 relevante artikler. Søk i referanselister avdekket 3 aktuelle artikler, totalt 122 artikler. S $\varnothing \mathrm{k}$ i databasen OpenGrey fra University of London ga ingen relevante treff. Det ble identifisert 42 duplikater gjennom EndNote. Titler og abstrakter ble gjennomgått, og 22 relevante artikler ble lest i fulltekst. Av disse fylte 6 artikler inklusjonskriteriene, og ble dermed inkludert i studien.

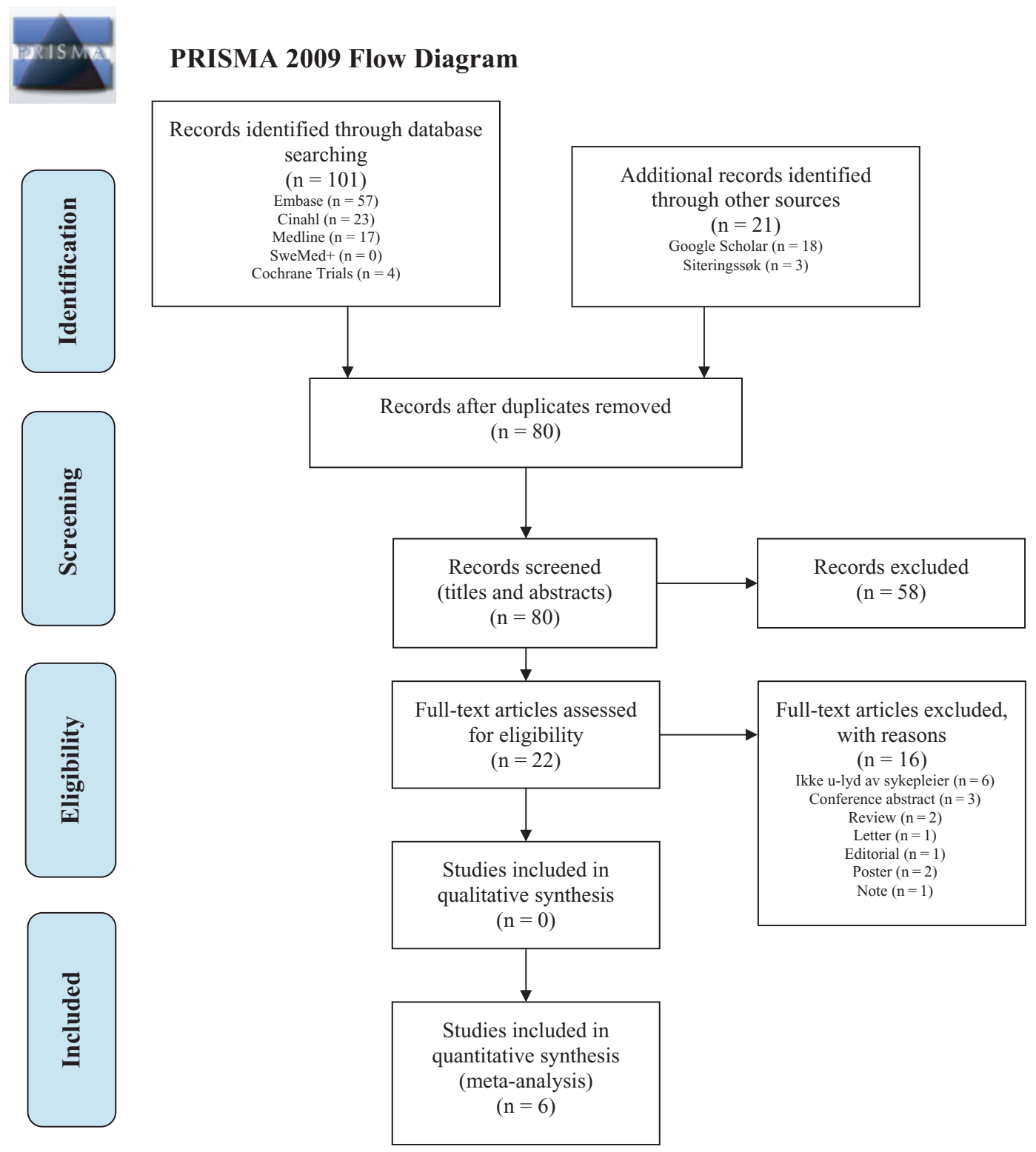

Figur 1: Prisma flytskjema From: Moher D, Liberati A, Tetzlaff J, Altman DG, The PRISMA Group (2009). Preferred Reporting Items for Systematic Reviews and Meta-Analyses: The PRISMA Statement. PLoS Med 6(7): e1000097. https://doi.org/10.1371/journal. pmed1000097. For more information, visit www.prisma-statement.org. 


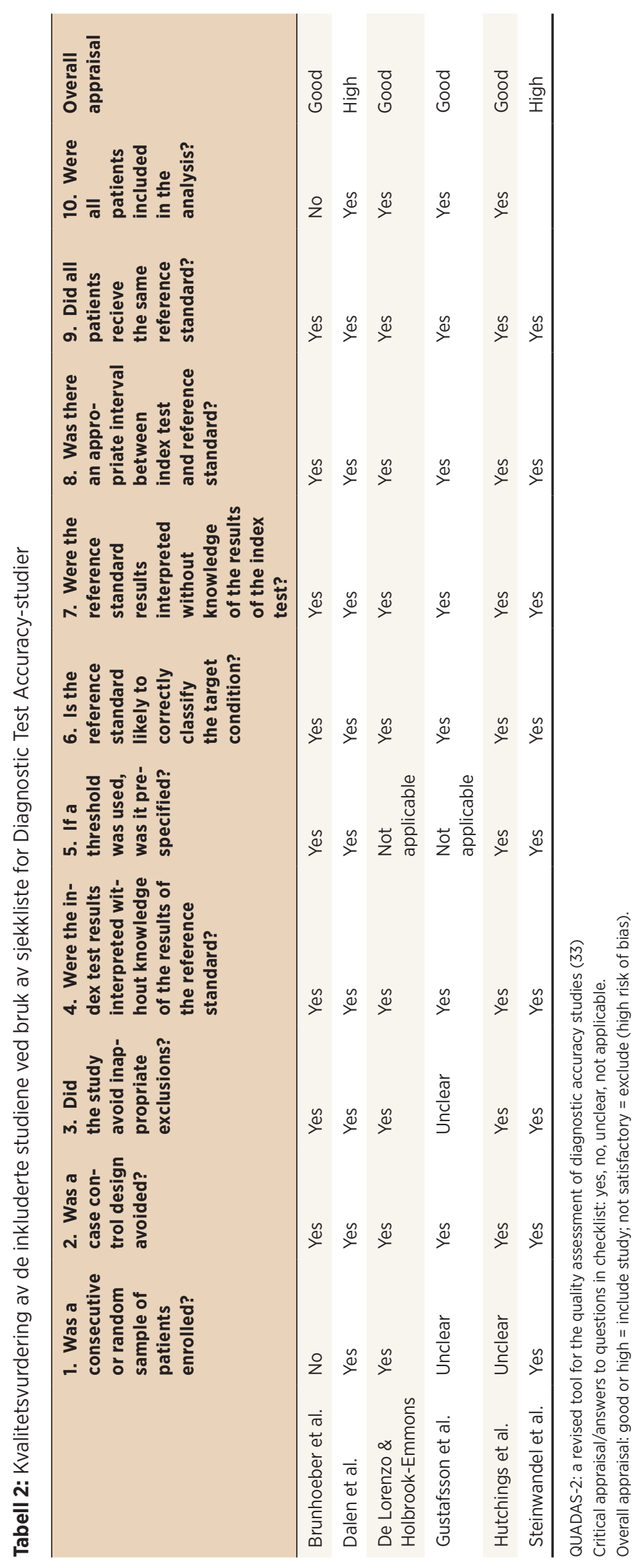




\section{Kvalitetsvurdering av inkluderte studier}

Etter å ha lest metodekapitlene til de inkluderte studiene nøye, ble alle studiene vurdert til å være Diagnostic Test Accuracy-studier (25,32). Artiklene ble kvalitetsvurdert ved hjelp av sjekklistene for Diagnostic Test Accuracy-studies fra Joanna Briggs Institute (33).

Kvaliteten på de inkluderte studiene ble vurdert til enten god eller høy (tabell 2). To studier ble vurdert til høy kvalitet $(34,35)$, der alle spørsmålene i sjekklisten ble besvart med «ja» (33). De resterende studiene ble vurdert til å ha god kvalitet, der noen av spørsmålene ble besvart med «nei» eller «ikke aktuelt». Alle de inkluderte studiene ble vurdert til å ha lav risiko for feil (bias). I to studier ble sykepleierne inkludert gjennom bekvemmelighetsutvalg $(36,37)$. I to studier var inklusjonsprosessen ikke godt beskrevet $(38,39)$. En studie hadde en skjevhet i populasjonen, der en av de inkluderte sykepleierne utførte $58 \%$ av ultralydunders $\varnothing$ kelsene (38). I en studie manglet relevante data i originalartikkelen (39), som senere ble identifisert i en posterpresentasjon (40).

\section{Dataekstraksjon}

Dataekstraksjon ble initialt utført av førsteforfatter og deretter ettergått av sisteforfatter. Resultatene fra dataekstraksjonen ble samlet i en litteraturmatrise (tabell 3). Data som ble hentet ut inkluderte forfatter, publikasjonsår og land, studiedesign, hensikt, type avdeling og pasientdiagnoser, antall sykepleiere og deres erfaring. Hvilken opplæring som ble gitt, hvor mange ultralydunders $\varnothing$ kelser som ble gjennomført, hvem sykepleierne ble sammenliknet med (ekspert), samt studienes resultater i grad av samsvar ble videre hentet ut.

\section{Statistiske analyser}

Statistiske beregninger for samsvar fra de inkluderte studiene ble hentet ut og samlet i en egen resultattabell for å få en bedre oversikt (tabell 4). Analysene anvendt i de inkluderte studiene baserte seg på nøyaktighet, korrelasjon, sensitivitet og spesifisitet, kappa og interclass correlation coefficient. Korrelasjonskoeffisienter som disse forteller om styrken på og retningen til en sammenheng. Resultatene fra enkeltstudiene ble deretter vurdert opp mot tolkningsstandarder for de statistiske beregningene relatert til den kliniske konteksten (27). Det ble fokusert på samsvar mellom sykepleierne inkludert i studiene og den legespesialisten de ble sammenliknet med. Resultatene fra enkeltstudiene ble vurdert for å gi et samlet resultat (27,41). Analysen er sammenstilt som en beskrivende oppsummering. 


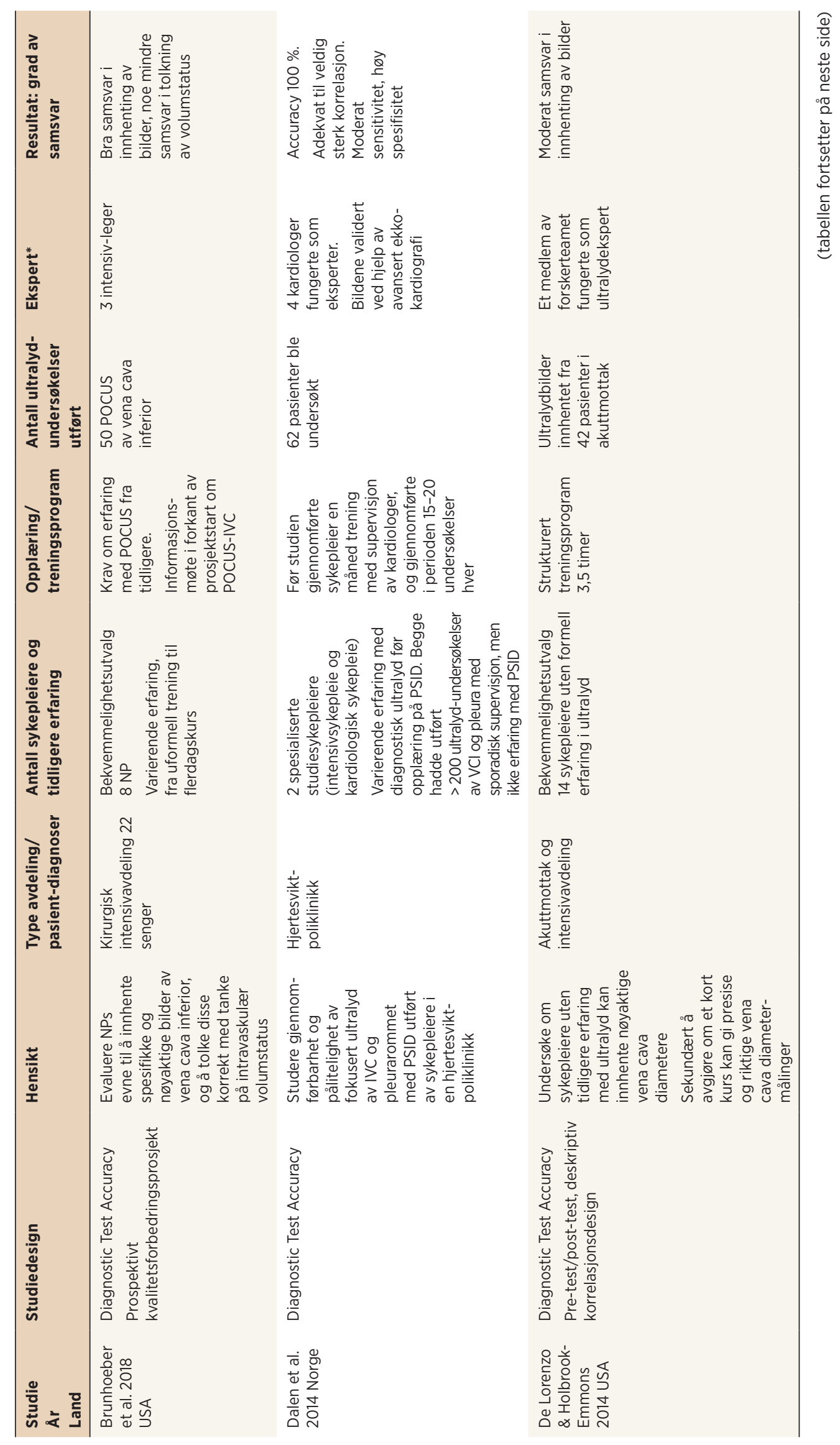




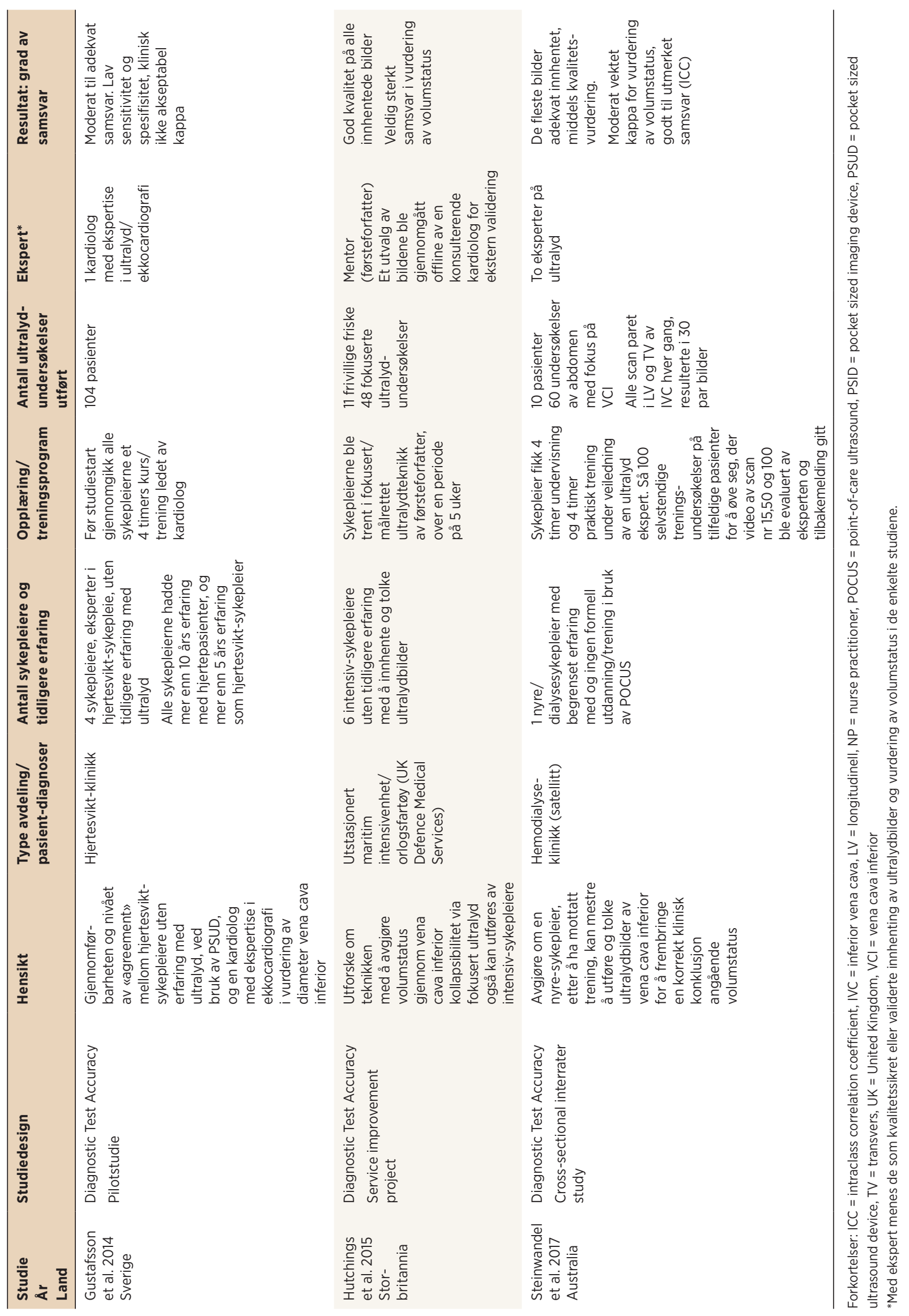




\section{Resultater}

\section{Karakteristika ved studiene}

Studiene som ble inkludert i denne systematiske litteraturstudien var publisert i tidsrommet 2014-2018, og kom fra Norge (34) Sverige (38), Storbritannia (39), USA (36,37) og Australia (35). Kvaliteten på innhentede ultralydbilder av vena cava inferior utført av sykepleier ble i alle studiene vurdert av leger med ulik ekspertise. Sykepleiernes evne til å tolke ultralydbildene korrekt med tanke på vurdering av volumstatus ble vurdert i 5 $(34-36,38,39)$ av de 6 inkluderte studiene. Studiene ble utført i ulike kliniske avdelinger, som hjertesviktpoliklinikk (34,38), akuttmottak (37), kirurgisk intensivavdeling (36), dialyseavdeling (35) og orlogsfartøy med intensivavdeling (39). Totalt 35 sykepleiere deltok i studiene. Antall sykepleiere som utførte ultralyd og vurderte volumstatus i de ulike studiene varierte fra 1 til 14 .

Utdanningsnivået til sykepleierne i de inkluderte studiene varierte mellom vanlig sykepleier, kardiologisk sykepleier, intensivsykepleier og Nurse Practitioner. De hadde ulik arbeidserfaring (1-18 år), med et snitt på ca. 5 års erfaring som sykepleier med en avansert funksjon. I en av studiene hadde sykepleierne variert erfaring med ultralyd, fra uformell trening på jobb til formelle flerdagskurs $\mathrm{i}$ «point-of-care ultrasound» (POCUS). Dette var et av kriteriene for inklusjon i denne studien (36).

Det var stor forskjell i opplæringen av sykepleierne i de inkluderte studiene. Sykepleiere fikk 3,5-8 timer undervisning eller kurs $(35,37,38)$. Én sykepleier ved en dialyseavdeling utførte deretter 100 selvstendige ultralydunders $\varnothing$ kelser med tilbakemeldinger fra ultralydekspert (35). I en studie ble det gjennomført et 5 ukers treningsprogram uten å spesifisere antall timer undervisning eller trening (39). Hjertesviktsykepleierne (34) hadde gjennomført mer enn 200 ultralydunders $\varnothing$ kelser med sporadisk supervisjon før studiestart, men hadde ikke erfaring med bruken av lommeultralydapparat (PSUD). De gjennomførte så 15-20 undersøkelser med PSUD i løpet av en måned under supervisjon av kardiolog. En regresjonsanalyse viste ikke signifikant korrelasjon mellom alderen og erfaringen til sykepleierne og deres evne til nøyaktig innhenting av ultralydbilder (37). Til sammen ble det utført 336 målrettede ultralydunders $\varnothing$ kelser av vena cava inferior.

\section{Samsvar i innhenting av ultralydbilder av vena cava inferior}

Det ble benyttet en rekke ulike statistiske beregninger i de inkluderte studiene (tabell 4). Samsvar i innhenting av ultralydbilder av vena cava inferior ble oppgitt som nøyaktighet (les: accuracy) i prosent i tre studier $(34,36,38)$. For samsvar i innhenting av bilder varierte resultatene fra $75^{-100} \%$. Sensitivitet (64\%) og spesifisitet (51 \%) for innhenting av ultralydbilder var oppgitt i én studie (38). Samme studie oppga en kappa-verdi ( $k=$ $0,39)$ på samsvar mellom sykepleier og kardiolog for maksimum diameter på vena cava inferior, svarende til «fair» (42) eller minimal (43).

For samsvar av ulike målinger av vena cava inferior var Pearsons $r(0,59-0,89)$ beregnet i 2 studier $(34,37)$. Dette tilsvarer korrelasjon mellom sykepleier og 


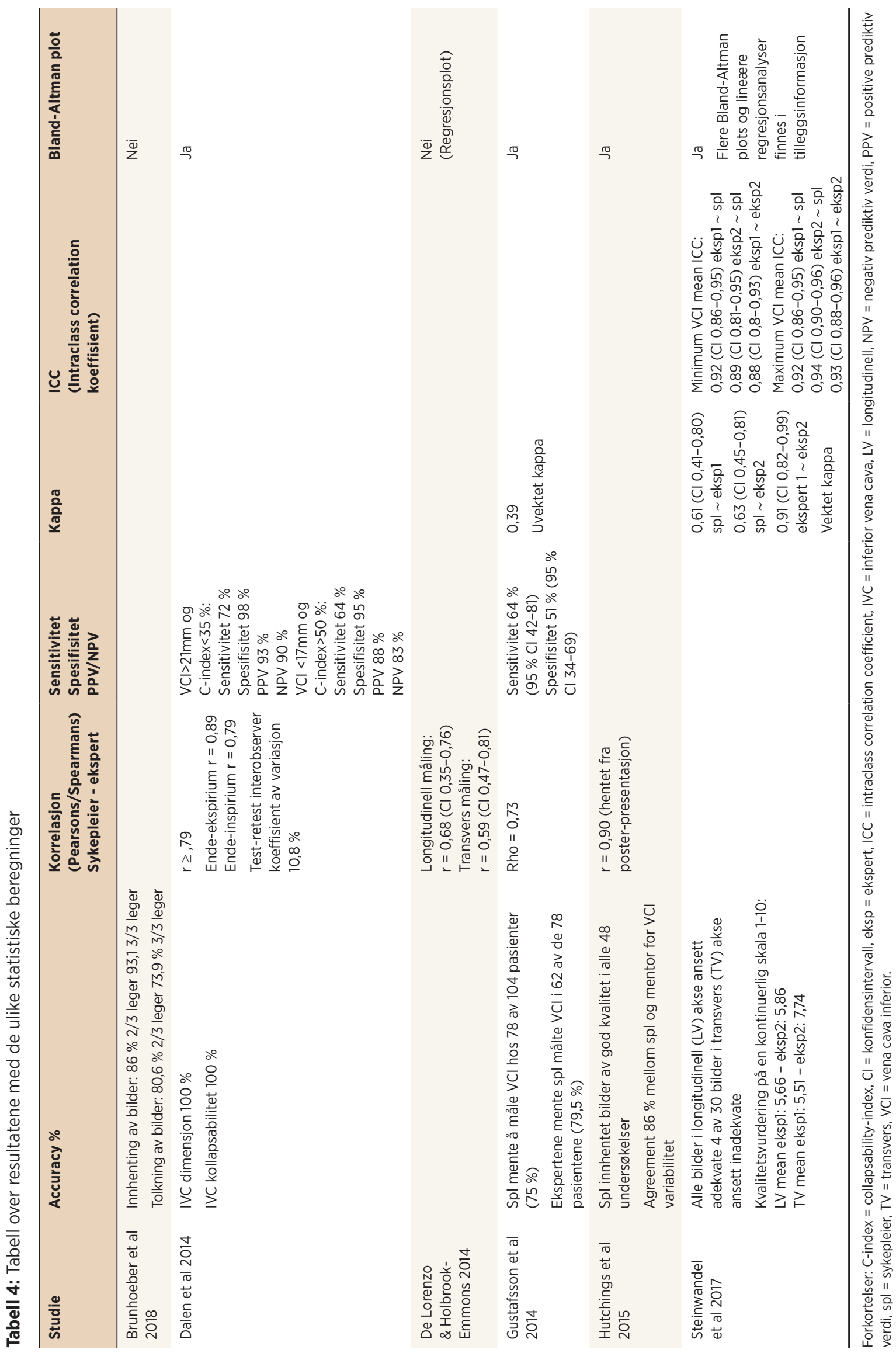


legespesialist fra moderat til veldig sterk (44). I en av studiene ble det oppgitt at intensivsykepleierne var i stand til å innhente bilder av god kvalitet i alle de utførte unders $\varnothing$ kelsene (39). I en annen studie ble 4 av 60 innhentede bilder vurdert til å ikke være korrekt innhentet.

\section{Samsvar i vurdering av volumstatus}

For vurdering av respirasjonsvariasjon eller kollapsabilitet av vena cava inferior ble det oppgitt overenstemmelse mellom sykepleier og legespesialist på 86-100 \% (34,35,39). Moderat sensitivitet (64-72\%) og høy spesifisitet (95-98\%) for sykepleiers evne til å gjøre korrekte tolkninger av vena cava inferior med tanke på volumstatus var oppgitt i én studie (34). Positiv prediktiv verdi (PPV) (88-93\%) og negativ prediktiv verdi (NPV) (83-90 \%) ble beregnet i samme studie (34). I en studie (39) var $r$-verdien ikke oppgitt i originalartikkelen, men gjennom søk etter tilleggsopplysninger ble det avdekket en poster-presentasjon (40) som oppga $r=0,90$ for korrelasjon mellom sykepleiere og mentor. Dette tilsvarer utmerket korrelasjon (44). For korrelasjon mellom sykepleiernes og legespesialistenes vurderinger av volumstatus hadde en studie oppgitt $R h o=0,73$ (38) som ble vurdert å være moderat eller tilfredsstillende $(27,44)$. Kappa-verdiene oppgitt for samsvar mellom sykepleierens og ultralydekspertenes tolkninger av volumstatus $(0,61-0,63)(35)$ vurderes som moderat til betydelig $(42,43)$. Intraclass Correlation Coefficient (ICC) svarer til godt samsvar mellom sykepleier og de to ultralydekspertene. ICC mellom de to ultralydekspertene var god $(0,88-0,93)(35)$.

\section{Blinding og ekstern validering av innhentede bilder}

I alle studiene ble det utført blinding mellom vurderingene til sykepleierne og de ulike legespesialistene. I en studie var det undersøkelsene sykepleierne utførte med et lommeultralydapparat som ble sammenliknet med unders $\varnothing$ kelsene kardiolog gjorde med et avansert ekko-apparat (34). Én av studiene sendte noen av bildene til ekstern validering hos kardiolog (39).

\section{Diskusjon}

Hensikten med denne systematiske litteraturstudien var å unders $\varnothing \mathrm{ke}$ om sykepleiere med en avansert funksjon kan utføre målrettet ultralyd av vena cava inferior for vurdering av volumstatus hos voksne pasienter.

\section{Innhenting av korrekte ultralydbilder av vena cava inferior}

Resultatene indikerer at sykepleiere med avanserte funksjoner kan innhente bilder av vena cava inferior med tilfredsstillende kvalitet. I to av studiene ble alle ultralydbildene vurdert av legespesialistene til å være korrekt innhentet eller av god kvalitet $(34,39)$. Det var moderat til godt samsvar mellom sykepleiere og legespesialister for korrekt innhentede bilder og identifisering av vena cava inferior $(36,38)$. Eksisterende 
forskning har vist at leger i spesialisering (LIS) og medisinstudenter oppnådde akseptabel organpresentasjon i mer enn $77 \%$ av ultralydunders $\varnothing$ kelsene av vena cava inferior $(45,46)$. I begge disse studiene er LIS og medisinstudenter sammenliknet med ulike legespesialister, og resultatene samsvarer godt med resultatene sykepleierne inkludert i litteraturstudien oppnådde. I studien til Mjølstad et al. (45) spenner resultatene fra svakt til moderat samsvar. Dette indikerer at sykepleiere er i stand til å innhente ultralydbilder med til dels bedre samsvar med legespesialistene, sammenliknet med medisinstudenter og LIS.

Fysiologiske målinger innhentet ved hjelp av ultralyd er sterkt avhengig av utøveren (47,48), og har potensiale til å ha innflytelse på behandlingsvalg (49). Sykepleierne identifiserte vena cava inferior i $100 \%$ av de gjennomførte unders $\varnothing$ kelsene i studien til Dalen et al. (34), og hadde sterk korrelasjon $(44,50)$ med legespesialistene for målinger av diameter av vena cava inferior. Resultatene fra de inkluderte studiene indikerte at det var moderat til utmerket korrelasjon mellom bildene innhentet av sykepleiere sammenliknet med ulike legespesialister. Akkaya et al. (48) fant moderat overenstemmelse (42) da de unders $\varnothing$ kte interrater reliabilitet mellom leger i spesialisering innen akuttmedisin. Resultatene deres er ikke ulike resultatene fra studiene inkludert i litteraturstudien. Ultralyd er en sanntidsunders $\varnothing$ kelse som er rask, non-invasiv og lett repeterbar, der den viktigste begrensningen er at den er avhengig av kompetansen og erfaringen til utøveren (48). Feilmålinger kan medføre at behandling ordineres på feil grunnlag, og forårsake negative konsekvenser for pasienten. Hos pasienter med for eksempel sjokk, kan det føre til uheldige ordinasjoner av væsketilførsel til pasienter som allerede er hypervoleme (1-4,47). Resultatene fra de inkluderte studiene vitner om at hvilken utdanning de som utfører slike undersøkelser har ikke er avgjørende. Det er hvilken erfaring de har opparbeidet seg med disse unders $\varnothing$ kelsene som er viktig. Forskning har vist at det er større variasjon i innhentingen av ultralydbilder enn i tolkningen av disse (51). Innhentingen av bilder viser seg å være vanskelig å gjenskape, og indikerer at det er dette opplæring og trening bør fokusere på.

\section{Pålitelige tolkninger av vena cava inferior for vurdering av volumstatus}

Funnene fra denne litteraturstudien viste at sykepleiere med avanserte funksjoner kan gjøre tolkninger av vena cava inferior med tanke på vurdering av volumstatus hos voksne pasienter med gode resultater. Sykepleiernes prestasjoner tilsvarte prestasjonene til leger med begrenset erfaring $(46,48,52)$. Dalen et al. (34) fant moderat sensitivitet når det gjaldt å oppdage hypervolemi og hypovolemi, med høy spesifisitet for de samme målingene. Dette kan forstås slik at det var høy sannsynlighet for at sykepleierne korrekt bekreftet at pasienter hadde normal volumstatus. I den aktuelle studien vurderte sykepleierne diagnosen korrekt i 88-93\% av tilfellene (34). Sykepleiernes vurderinger av volumstatus vil dermed kunne være avgjørende for videre behandling, som for eksempel endringer i dosering av diuretika til pasienter med hjertesvikt og planlegging av væsketrekk hos dialysepasienter (17,47,53). 
En av de inkluderte studiene (35) fant betydelig til utmerket samsvar $(42,54)$ mellom sykepleieren og ultralydekspertene for vurdering av volumstatus. Resultatene er i stor grad sammenfallende med, og til dels bedre enn, resultatene fra studier som unders $\varnothing$ kte korrelasjon mellom leger med ulik erfaringsbakgrunn $(49,54,55)$. Dette tyder på at sykepleier kan gjøre vurderinger av volumstatus basert på ultralyd av vena cava inferior med resultater som stemmer godt med resultatene til leger med varierende erfaring.

Flere av de inkluderte studiene $(34,35,38,39)$ har beskrevet adekvat, svært sterk eller utmerket korrelasjon mellom sykepleierne og de ulike legespesialistene i målinger for respirasjonsvariabilitet for vena cava inferior eller vurderinger av volumstatus. Dette vitner om at det er mulig for sykepleiere å gjøre gode vurderinger av volumstatus ved hjelp av ultralyd av vena cava inferior, og at de i stor grad oppnår samme resultater som ulike legespesialister med lang erfaring.

\section{Hvordan opplæring og trening påvirker resultatene}

Det er et gjennomgående trekk i de inkluderte studiene at sykepleierne fikk relativt kort opplæring i ultralyd av vena cava (35,37-39). Det kan diskuteres om det er rimelig å sammenlikne legespesialister med lang og dokumentert erfaring med sykepleiere som har liten erfaring med samme ferdighet. En studie som sammenliknet novise og ekspert innen akuttmedisin fant lav interrater agreement mellom målingene utført av novisen og eksperten når det gjaldt vurdering av volumstatus, samt at forskjellene var større enn det som er klinisk akseptabelt (52). Dette illustrerer at det ikke er yrkestittelen til den som utfører undersøkelsen som er viktig, men graden av kyndighet. Novisene fikk 2 timer undervisning og trening i grunnleggende ultralydunders $\varnothing$ kelser av vena cava inferior (52). Dette er sammenliknbart med undervisningen og treningen som sykepleierne i de inkluderte studiene fikk. Unntaket er intensivsykepleierne, som fikk 5 ukers opplæring (39), og hjertesviktsykepleierne, som hadde utført mer enn 200 ultralydunders $\varnothing$ kelser, men ikke hadde erfaring med PSUD som ble brukt i studien (34). Hos Steinwandel et al. (35) utførte sykepleieren 100 selvstendige ultralydunders $\varnothing$ kelser med tilbakemelding fra ultralydekspert etter gjennomført undervisning. Det er nærliggende å tenke at erfaringen sykepleierne opparbeidet seg påvirket resultatene i positiv retning. En mulighet til å opparbeide seg og opprettholde ferdigheter i ultralyd, vil kunne bidra til å kvalitetssikre målingene som gjøres. Dette vil igjen kunne resultere i hyppigere bruk av slik ultralyd (46). Hos Gustafsson et al. (38) var sykepleierne som deltok blant de som fikk kortest opplæring, kun 4 timer med kardiolog. Det kan ikke utelukkes at resultatene deres hadde vært bedre dersom de hadde fått mer opplæring eller trening.

Det finnes ingen retningslinje for hvor mye undervisning som kreves for å utføre POCUS i akuttmottak og intensivavdelinger, men det anbefales 20-30 timer for intensivleger (13). Anbefalingen står i sterk kontrast til undervisningen sykepleierne i de inkluderte studiene fikk, kun 3,5-8 timer undervisning og trening (35,37,38). European Association of Cardiovascular Imaging kom i 2018 med en anbefaling for bruken av håndholdte ultralydapparater (HUD), som sier at kun operatører med tilstrekkelig trening bør bruke HUD 
i kliniske situasjoner. Under slike forutsetninger kan operatører med ulik bakgrunn og definert ekspertise, for eksempel sykepleiere, bruke slike apparater (56). Anbefalingen støtter at oppgaveforskyvning, der sykepleier tar større ansvar for klinisk unders $\varnothing$ kelsesmetodikk og beslutninger på avansert nivå, kan være til fordel for pasientene (21). Studier som undersøkte samsvar mellom leger med ulik erfaring, fant signifikant forbedring for vurdering av hypo- og hypervolemi når deltakerne hadde utført henholdsvis mer enn 5 (55) og 10 (48) unders $\varnothing$ kelser av vena cava inferior. Et grunnleggende pensum og et undervisningsopplegg som inkluderte både teori og praksis ga best resultater. Trening på opptil 10 timer eller minimum 30 ultralydunders $\varnothing$ kelser forbedret kompetansen, som i denne sammenheng ble definert som evnen til både å innhente og tolke ultralydbildene korrekt (57). Det er liten grunn til å anta at dette skulle være annerledes for sykepleiere.

\section{Reliabilitet og validitet ved de inkluderte studiene}

En utfordring i forhold til validitet i denne studien er den statistiske styrken. Dersom små utvalg benyttes, vil den statistiske validiteten bli lavere og utvalget mindre representativt for hele populasjonen (27). Kun to av studiene oppga at de hadde beregnet det antallet pasienter som det var ønskelig å inkludere for å muliggjøre statistiske beregninger (37,38). Studier av diagnostiske testers nøyaktighet har ofte begrenset omfang, som kan medføre at påliteligheten og presisjonen til resultatene begrenses. Når slike studier utføres korrekt, vil det likevel være lav risiko for bias i studienes resultater $(32,58)$. Alle de inkluderte studiene ble ansett å være tilfredsstillende utført (tabell 2), og det er rimelig å anta at man da kan stole på resultatene.

Mangel på tilgjengelige ressurser kan medføre at studier baseres på små utvalg, og av samme årsak blir bekvemmelighetsutvalg ofte benyttet innen sykepleieforskning (27). To av de inkluderte studiene benyttet seg av bekvemmelighetsutvalg $(36,37)$, mens i to studier ble ikke inklusjonsprosessen godt nok beskrevet til at seleksjonsbias kunne vurderes $(38,39)$. Det er rimelig å anta at sykepleierne inkludert gjennom egen-seleksjon hadde en ekstra interesse for ultralyd eller et $\varnothing n s k e$ om en mer selvstendig sykepleierrolle. Dette kan igjen ha gitt seg utslag i en entusiasme som $\varnothing$ ker viljen og innsatsen i å lære seg ferdighetene som kreves for å innhente korrekte ultralydbilder og gjøre gode vurderinger av disse (46).

Brunhoeber et al. (36) inkluderte kun sykepleiere som hadde erfaring med ultralyd fra tidligere, mens Dalen et al. (34) inkluderte sykepleiere som hadde utført over 200 ultralydundersøkelser av vena cava inferior og pleura. De resterende (35,37-39) inkluderte kun sykepleiere uten, eller svært begrenset erfaring med ultralyd. Hver for seg vil de inkluderte studiene ha begrenset overføringsverdi. Samlet i denne systematiske litteraturstudien vil derimot den samme heterogeniteten trolig representere den reelle sykepleierpopulasjonen rimelig godt, der tidligere erfaring, interesseområde og opplæring varierer (27).

I enkelte av studiene ble bildene der sykepleierne og legespesialistene ikke var enige om identifisering av vena cava inferior utelatt fra videre beregninger av samsvar. 
I Brunhoeber et al. (36) sin studie ble ultralydbilder som ingen av legespesialistene var enige i at var valide utelatt. Derimot inkluderte Gustafsson et al. (38) i sin beregning av korrelasjon kun ultralydbildene sykepleierne selv mente var valide. Slik eksklusjon av ultralydbilder, som beskrevet over, kan påvirke tolkningen av enkeltstudiene ved at resultatene fremstår som mer nøyaktig enn de egentlig er $(25,26)$.

\section{Begrensninger ved studien}

Som ved enhver systematisk litteraturgjennomgang, kan forfatterne ikke utelukke at det finnes relevant forskning som ikke er identifisert gjennom det systematiske søket. For å begrense risikoen for manglende funn, kunne det vært utført håndsøk i internasjonale tidsskrift. Det ble ikke gjort for denne studien.

Hver av de inkluderte studiene var små, med få sykepleiere inkludert. Studiene ble utført i til dels svært ulike avdelinger, eksempelvis poliklinikk og intensivavdeling. En av studiene ble gjennomført på friske frivillige deltakere (39), der de resterende ble utført på pasienter med ulike diagnoser. Opplæringsgrunnlaget i de inkluderte studiene var ulikt, der enkelte studier inkluderte sykepleiere uten noe erfaring med ultralyd, mens andre inkluderte sykepleiere som i ulik grad hadde uført ultralyd tidligere.

\section{Konklusjon}

Resultatene fra denne systematiske litteraturstudien viser at sykepleiere med en avansert funksjon kan innhente korrekte ultralydbilder og utføre pålitelige vurderinger av volumstatus ved hjelp av ultralyd av vena cava inferior. Funnene viser at det er viktig med tilstrekkelig opplæring og trening før sykepleiere med en avansert funksjon påtar seg denne oppgaven.

\section{Implikasjoner for sykepleiepraksis}

Denne studien kan være et bidrag i en diskusjon der sykepleiere med en avansert funksjon kan medvirke til nyskapning og utvikling i helsevesenet, ha en mer selvstendig utøvelse av sykepleie og påta seg et større ansvar innen klinisk undersøkelsesmetodikk på avansert nivå.

\section{Videre forskning}

Ettersom det ble identifisert kun seks relevante studier til denne systematiske litteraturstudien, tyder dette på at det er et behov for mer forskning på ultralyd av vena cava inferior utført av sykepleiere, og i hvilken grad det får kliniske konsekvenser. Det $b \varnothing r$ tilstrebes å gjennomføre studier med tilstrekkelig statistisk styrke. Videre anbefales å gjøre studier som har til hensikt å unders $\varnothing$ ke både innholdet i og lengden på opplæring som gis til sykepleiere som utfører ultralyd for vurdering av volumstatus. 


\section{Takk}

Forfatterne $\varnothing$ nsker å rette en stor takk til spesialbibliotekarene ved Lovisenberg Diakonale Høgskole og Medisinsk fag- og forskningsbibliotek ved Akershus universitetssykehus, spesielt Åse Marit Hammersbøen, for god hjelp til planlegging og gjennomføring av de opprinnelige søkene, samt gjennomføring av oppdaterte $s \varnothing \mathrm{k}$.

\section{Litteraturliste}

1. Long E, Oakley E, Duke T, Babl FE. Does respiratory variation in inferior vena cava diameter predict fluid responsiveness: a systematic review and meta-analysis. Shock. 2017;47(5):550-9. https://doi. org/10.1097/SHK.0000000000000801

2. Si X, Xu H, Liu Z, Wu J, Cao D, Chen J, et al. Does respiratory variation in inferior vena cava diameter predict fluid responsiveness in mechanically ventilated patients? A systematic review and metaanalysis. Anesth Analg. 2018;127(5):1157-64. https://doi.org/10.1213/ane.0000000000003459

3. Orso D, Paoli I, Piani T, Cilenti FL, Cristiani L, Guglielmo N. Accuracy of ultrasonographic measurements of inferior vena cava to determine fluid responsiveness: a systematic review and metaanalysis. J Intensive Care Med. 2020;35(4):354-63. https://doi.org/10.1177/0885066617752308

4. Bednarczyk JM, Fridfinnson JA, Kumar A, Blanchard L, Rabbani R, Bell D, et al. Incorporating dynamic assessment of fluid responsiveness into goal-directed therapy: a systematic review and metaanalysis. Crit Care Med. 2017;45(9):1538-45. https://doi.org/10.1097/ccm.0000000000002554

5. Tigabu BM, Davari M, Kebriaeezadeh A, Mojtahedzadeh M. Fluid volume, fluid balance and patient outcome in severe sepsis and septic shock: a systematic review. J Crit Care. 2018;48:153-9. https://doi. org/10.1016/j.jcrc.2018.08.018

6. Gaieski DF, Mikkelsen ME. Evaluation of and initial approach to the adult patient with undifferentiated hypotension and shock. I: Finlay G, red. UpToDate. Wolters Kluwer; 2019.

7. Schmidt GA, Mandel J. Evaluation and management of suspected sepsis and septic shock in adults. I: Finlay G, red. UpToDate. Wolters Kluwer; 2019.

8. Das SK, Choupoo NS, Pradhan D, Saikia P, Monnet X. Diagnostic accuracy of inferior vena caval respiratory variation in detecting fluid unresponsiveness: a systematic review and meta-analysis. Eur J Anaesthesiol. 2018;35(11):831-9. https://doi.org/10.1097/eja.0000000000000841

9. Pourmand A, Pyle M, Yamane D, Sumon K, Frasure SE. The utility of point-of-care ultrasound in the assessment of volume status in acute and critically ill patients. World J Emerg Med. 2019;10(4):232-8. https://doi.org/10.5847/wjem.j.1920-8642.2019.04.007

10. Preau S, Bortolotti P, Colling D, Dewavrin F, Colas V, Voisin B, et al. Diagnostic accuracy of the inferior vena cava collapsibility to predict fluid responsiveness in spontaneously breathing patients with sepsis and acute circulatory failure. Crit Care Med. 2017;45(3):e290-e7. https://doi.org/10.1097/ CCM.0000000000002090

11. Thanakitcharu P, Charoenwut M, Siriwiwatanakul N. Inferior vena cava diameter and collapsibility index: a practical non-invasive evaluation of intravascular fluid volume in critically-ill patients. J Med Assoc Thai. 2013;96(Suppl 3):S14-22.

12. Rhodes A, Evans LE, Alhazzani W, Levy MM, Antonelli M, Ferrer R, et al. Surviving sepsis campaign: international guidelines for management of sepsis and septic shock: 2016. Intensive Care Med. 2017;43(3):304-77. https://doi.org/10.1007/s00134-017-4683-6

13. Chen L, Malek T. Point-of-care ultrasonography in emergency and critical care medicine. Crit Care Nurs Q. 2018;41(2):94-101. https://doi.org/10.1097/CNQ.0000000000000190 
14. Laher AE, Watermeyer MJ, Buchanan SK, Dippenaar N, Simo NCT, Motara F, et al. A review of hemodynamic monitoring techniques, methods and devices for the emergency physician. Am J Emerg Med. 2017;35(9):1335-47. https://doi.org/10.1016/j.ajem.2017.03.036

15. Varndell W, Topacio M, Hagness C, Lemon H, Tracy D. Nurse-performed focused ultrasound in the emergency department: a systematic review. Australas Emerg Care. 2018;21(4):121-30. https://doi. org/10.1016/j.auec.2018.09.003

16. Graven T, Wahba A, Hammer AM, Sagen O, Olsen $\varnothing$, Skjetne K, et al. Focused ultrasound of the pleural cavities and the pericardium by nurses after cardiac surgery. Scand Cardiovasc J. 2015;49(1):56-63. https://doi.org/10.3109/14017431.2015.1009383

17. Steinwandel U, Gibson NP, Rippey JC, Towell A, Rosman J. Use of ultrasound by registered nurses a systematic literature review. J Ren Care. 2017;43(3):132-42. https://doi.org/10.1111/jorc.12191

18. Gundersen GH, Norekval TM, Haug HH, Skjetne K, Kleinau JO, Graven T, et al. Adding point of care ultrasound to assess volume status in heart failure patients in a nurse-led outpatient clinic. A randomised study. Heart. 2016;102(1):29-34. https://doi.org/10.1136/heartjnl-2015-307798

19. Cover M, Tafoya C, Long B, Cranford J, Burkhardt J, Huang R, et al. Creation of a flight nurse critical care ultrasound program. Air Med J. 2019;38(4):266-72. https://doi.org/https://doi.org/10.1016/j. amj.2019.03.010

20. Jørgensen M, Gundersen GH. Målrettet ultralyd til hjertepasienter. Sykepleien Forskning. 2017;105(4):58-61. https://doi.org/10.4220/Sykepleiens.2017.61325

21. Fagerström L. Avansert klinisk sykepleie - et begrunnet behov. I: Fagerström L, red. Avansert klinisk sykepleie. 1 utg. Oslo: Gyldendal Akademisk; 2019. s. 17-29.

22. Delamaire M-L, Lafortune G. Nurses in advanced roles: a description and evaluation of experiences in 12 developed countries. OECD Health Working Papers. 2010;54. https://doi.org/10.1787/5kmbrcfms597en

23. Fagerström L. Hva er avansert klinisk sykepleie? I: Fagerström L, red. Avansert klinisk sykepleie. 1 utg. Oslo: Gyldendal Akademisk; 2019. s. 39-50.

24. ICN Nurse Pracitioner/Advanced Practice Nursing Network. Definition and characteristics of the role: International Council of Nurses (ICN) 2019. Tilgjengelig fra: https://international.aanp.org/ Practice/APNRoles.

25. Campbell JM, Klugar M, Ding S, Carmody DP, Hakonsen SJ, Jadotte YT, et al. Diagnostic test accuracy: methods for systematic review and meta-analysis. Int J Evid-Based Hea. 2015;13(3):154-62. https://doi.org/10.1097/xeb.0000000000000061

26. Campbell JM, Kulgar M, Ding S, Carmody DP, Hakonsen SJ, Jadotte YT, et al. Diagnostic test accuracy systematic reviews. The Joanna Briggs Institute; 2017. Tilgjengelig fra: https://wiki.joannabriggs.org/ display/MANUAL/Chapter+9\%3A+Diagnostic+test+accuracy+systematic+reviews

27. Polit DF, Beck CT. Nursing research - generating and assessing evidence for nursing practice. 11 utg. Philadelphia: Wolters Kluwer; 2021.

28. McInnes MDF, Moher D, Thombs BD, McGrath TA, Bossuyt PM, Clifford T, et al. Preferred reporting items for a systematic review and meta-analysis of diagnostic test accuracy studies: the PRISMA-DTA statement. JAMA. 2018;319(4):388-96. https://doi.org/10.1001/jama.2017.19163

29. Helsebiblioteket.no. Kunnskapsbasert praksis - Litteraturs $\varnothing \mathrm{k}$ - Lage søkestrategi. 2016.

30. Nasjonalt kunnskapssenter for helsetjenesten. Slik oppsummerer vi forskning. Håndbok for Nasjonalt kunnskapssenter for helsetjenesten. Oslo;2015. Tilgjengelig fra: https://www.fhi.no/kk/oppsummertforskning-for-helsetjenesten/hva-er-en-kunnskapsoppsummering/.

31. Moher D, Liberati A, Tetzlaff J, Altman DG. Preferred reporting items for systematic reviews and meta-analyses: the PRISMA statement. BMJ. 2009;339:b2535. https://doi.org/10.1136/bmj.b2535 
32. Cohen JF, Korevaar DA, Altman DG, Bruns DE, Gatsonis CA, Hooft L, et al. STARD 2015 guidelines for reporting diagnostic accuracy studies: explanation and elaboration. BMJ Open. 2016;6(11):e012799. https://doi.org/10.1136/bmjopen-2016-012799

33. Whiting PF, Rutjes AW, Westwood ME, Mallett S, Deeks JJ, Reitsma JB, et al. QUADAS-2: a revised tool for the quality assessment of diagnostic accuracy studies. Ann Intern Med. 2011;155(8):529-36. https://doi.org/10.7326/0003-4819-155-8-201110180-00009

34. Dalen H, Gundersen GH, Skjetne K, Haug HH, Kleinau JO, Norekval TM, et al. Feasibility and reliability of pocket-size ultrasound examinations of the pleural cavities and vena cava inferior performed by nurses in an outpatient heart failure clinic. Eur J Cardiovasc Nurs. 2014;14(4):286-93. https://doi.org/10.1177/1474515114547651

35. Steinwandel U, Gibson N, Towell A, Rippey JJR, Rosman J. Can a renal nurse assess fluid status using ultrasound on the inferior vena cava? A cross-sectional interrater study. Hemodial Int. 2018;22(2):261-9. https://doi.org/10.1111/hdi.12606

36. Brunhoeber LA, King J, Davis S, Witherspoon B. Nurse practitioner use of point-of-care ultrasound in critical care. J Nurse Pract. 2018;14(5):383-8. https://doi.org/10.1016/j.nurpra.2017.12.002

37. De Lorenzo RA, Holbrook-Emmons VL. Ultrasound measurement of inferior vena cava diameters by emergency department nurses. Adv Emerg Nurs J. 2014;36(3):271-8. https://doi.org/10.1097/ TME.0000000000000025

38. Gustafsson M, Alehagen U, Johansson P. Pocket-sized ultrasound examination of fluid imbalance in patients with heart failure: a pilot and feasibility study of heart failure nurses without prior experience of ultrasonography. Eur J Cardiovasc Nurs. 2015;14(4):294-302. https://doi. org/10.1177/1474515114559435

39. Hutchings S, Bisset L, Cantillon L, Keating-Brown P, Jeffreys S, Muzvidziwa C, et al. Nurse-delivered focused echocardiography to determine intravascular volume status in a deployed maritime critical care unit. J R Nav Med Serv. 2015;101(2):124-8. https://pubmed.ncbi.nlm.nih.gov/26867411/

40. Hutchings SD, Bisset L, Cantillon L, Keating-Brown P, Jeffreys S, Muzvidziwa C, et al. Nurse delivered focused echocardiography to determine intravascular volume status in a deployed maritime critical care unit. Intensive Care Med Exp. 2015;3(Suppl 1):A919. https://doi.org/10.1186/2197-425X-3-S1-A919

41. Helsebiblioteket.no. Kunnskapsbasert praksis - Kritisk vurdering - Systematiske oversikter. 2016.

42. Landis JR, Koch GG. The measurement of observer agreement for categorical data. Biometrics. 1977:159-74.

43. McHugh ML. Interrater reliability: the kappa statistic. Biochem med. 2012;22(3):276-82. Tilgjengelig fra: https://hrcak.srce.hr/89395

44. Akoglu H. User's guide to correlation coefficients. Turk J Emerg Med. 2018;18. https://doi. org/10.1016/j.tjem.2018.08.001

45. Mjølstad OC, Andersen GN, Dalen H, Graven T, Skjetne K, Kleinau JO, et al. Feasibility and reliability of point-of-care pocket-size echocardiography performed by medical residents. Eur Heart J Cardiovasc Imaging. 2013;14(12):1195-202. https://doi.org/10.1093/ehjci/jeto62

46. Andersen GN, Viset A, Mjolstad OC, Salvesen O, Dalen H, Haugen BO. Feasibility and accuracy of point-of-care pocket-size ultrasonography performed by medical students. BMC Med Educ. 2014;14:156. https://doi.org/10.1186/1472-6920-14-156

47. Lucas BP, D’Addio A, Block C, Manning HL, Remillard B, Leiter JC. Clinical measurements obtained from point-of-care ultrasound images to assess acquisition skills. Ultrasound J. 2019;11(1):4. https:// doi.org/10.1186/s13089-019-0119-6

48. Akkaya A, Yesilaras M, Aksay E, Sever M, Atilla OD. The interrater reliability of ultrasound imaging of the inferior vena cava performed by emergency residents. Am J Emerg Med. 2013;31(10):1509-11. https://doi.org/https://doi.org/10.1016/j.ajem.2013.07.006 
49. Senthilnathan M, Kundra P, Mishra S, Velayudhan S, Pillai A. Competence of intensivists in focused transthoracic echocardiography in intensive care unit: a prospective observational study. Indian J Crit Care Med. 2018;22(5):340-5. https://doi.org/10.4103/ijccm.IJCCM_401_17

50. Chan YH. Biostatistics 104: correlational analysis. Singapore Med J. 2003;44(12):614-9.

51. Lucas BP, D’Addio A, Clark J, Block C, Manning H, Remillard B, et al. Reproducibility of point-ofcare ultrasonography for central vein diameter measurement: separating image acquisition from interpretation. J Clin Ultrasound. 2017;45(8):488-96. https://doi.org/10.1002/jcu.22491

52. Bowra J, Uwagboe V, Goudie A, Reid C, Gillett M. Interrater agreement between expert and novice in measuring inferior vena cava diameter and collapsibility index. Emerg Med Australas. 2015;27(4):295-9. https://doi.org/10.1111/1742-6723.12417

53. Dalen H, Gundersen G, Haug HH, Kleinau JO, Skjetne K, Norekvaal TM, et al. Superior clinical influence of implementing pocket-size focused ultrasound for early adaption of heart failure treatment in a nurse-led outpatient heart failure-a randomized cross-over study. Eur J Heart Fail. 2014;16:262. https://doi.org/10.1002/ejhf.93_18

54. Koo TK, Li MY. A guideline of selecting and reporting intraclass correlation coefficients for reliability research. J Chiropr Med. 2016;15(2):155-63. https://doi.org/https://doi.org/10.1016/j.jcm.2016.02.012

55. Fields JM, Lee PA, Jenq KY, Mark DG, Panebianco NL, Dean AJ. The interrater reliability of inferior vena cava ultrasound by bedside clinician sonographers in emergency department patients. Acad Emerg Med. 2011;18(1):98-101. https://doi.org/10.1111/j.1553-2712.2010.00952.x

56. Cardim N, Dalen H, Voigt J-U, Ionescu A, Price S, Neskovic AN, et al. The use of handheld ultrasound devices: a position statement of the European Association of Cardiovascular Imaging (2018 update). Eur Heart J Cardiovasc Imaging. 2018;20(3):245-52. https://doi.org/10.1093/ehjci/jey145

57. Kanji HD, McCallum JL, Bhagirath KM, Neitzel AS. Curriculum development and evaluation of a hemodynamic critical care ultrasound: a systematic review of the literature. Crit Care Med. 2016;44(8):e742-50. https://doi.org/10.1097/CCM.0000000000001661

58. Bossuyt PMM. Interpreting diagnostic test accuracy studies. Semin Hematol. 2008;45(3):189-95. https://doi.org/10.1053/j.seminhematol.2008.04.001 